$$
\begin{gathered}
\text { 서울지역 산업체 급식소 고객의 급식 나트륨 저감화 운영 및 } \\
\text { 필요성에 대한 인식 } \\
\text { 이 나 영 } \\
\text { 대전대학교 식품영양학과 }
\end{gathered}
$$

\title{
Customers' Perceptions of Operational Status of and Needs for Sodium Reduction in the Industry Foodservice in Seoul
}

\author{
Na-Young Yi ${ }^{\dagger}$ \\ Department of Food and Nutrition, Daejeon University, Daejeon, Korea. Professor
}

\section{Corresponding author Na-Young Yi \\ Department of Food and Nutrition, Daejeon University, Daejeon 34520, Korea.}

Tel: (042) 280-2468

Fax: (042) 280-2468

Email: nayoung1@dju.kr

\section{Acknowledgments}

This research was supported by the Daejeon University Research Grants (2019).

Received: January 4, 2020

Revised: February 6, 2020

Accepted: February 17, 2020

\begin{abstract}
Objectives: This study aimed to compare customers' perceptions of the need for a lowsodium diet and sodium-reduced operations in the industry foodservice by age. The relationships between health concerns and perceptions of the need for sodium-reduced operations and low-sodium diets in the industry foodservice were analyzed.
\end{abstract}

Methods: A survey was conducted among 340 industry foodservice customers aged 20-50 years and residing in Seoul, Korea. This study investigated the respondents' health concerns, their perception of the need for sodium-reduced foodservice operations, their perception of a sodium-reduced diet, and the general details of the foodservices they used. A cross-tabulation analysis and ANOVA were performed to identify differences in measurement items by age, and a simple regression analysis was performed to examine relationships between measurement items.

Results: For the customers' perception of the need for a sodium-reduced foodservice operation, the item "it is necessary to provide separate spices and sauces to reduce sodium intake" achieved the highest score (3.88 points out of a possible 5 points). For the perception of a sodium-reduced diet, the item "I think it is helpful for one's health" obtained the highest score (4.13 points). Respondents' health concerns had a positive effect on increasing the level of perception of the need for sodium-reduced foodservice operations and that of a sodium-reduced diet.

Conclusions: Foodservice nutritionists could help enhance their customers' perceptions of the needs for sodium-reduced foodservice operations and sodium-reduced diets by frequently providing them with sodium-related health information.

Korean J Community Nutr 25(1): 21 31, 2020

KEY WORDS industry foodservice, perception, health concern, sodium reduction, lowsodium diet

This is an Open-Access article distributed under the terms of the Creative Commons Attribution Non-Commercial License (http:// creativecommons.org/licenses/by-nc/3.0) which permits unrestricted non-commercial use, distribution, and reproduction in any medium, provided the original work is properly cited. 


\section{서 론}

나트륨의 과잉섭취는 고혈압, 뇌졸중, 심근경색, 심장질환, 그 외 당뇨병, 비만과 같은 만성질환의 원인이 된다 [1-4]. 우리나라 고혈압 환자는 604만명으로 연평균 $2.3 \%$ 증가하 고 있고, 고혈압 진료비는 3 조 1,032 억원으로 연 평균 $3.8 \%$ 증가하고 있다 [5]. 다양한 나트륨 저감화 정책과 사업은 심 혈관계 질환 환자의 비율을 감소시켜 의료비 대비 경제적 효 과가 높은 것으로 알려져 있다[6]. 2015 한국인영양소섭취 기준 [7]의 나트륨 하루 목표섭취량은 $2,000 \mathrm{mg}$ 이고, 세계 보건기구 (WHO) [8] 에서도 나트륨을 하루 $2,000 \mathrm{mg}$ 이하 로 섭취할 것을 권장하고 있다. 국민건강영양조사[5]에 의 하면 나트륨 섭취는 2010년 이후 점차 감소하고 있지만 2017년 1인 1일 평균 섭취량은 $3,478.3 \mathrm{mg}$ 으로 목표섭취 량보다 여전히 높은 수치를 보이고 있어, 지속적인 나트륨 저 감화 정책 추진이 필요하다. 우리나라는 급속한 산업화가 이 루어지면서 급식 이용자가 지속적으로 증가하여 급식은 국 민의 식생활에서 중요한 부분을 차지하게 되었다. 하루 한 끼 이상 급식을 제공 받고 있는 사람들이 매우 많아 단체급식에 의한 하루 나트륨 섭취의 비중이 크므로 [5] 국민의 식습관 개선과 나트륨 저감화를 위한 환경 조성을 위하여 급식의 체 계적인 식단운영 및 관리가 필요하다.

국가마다 만성질환 감소를 위한 전략의 하나로 다양한 나 트륨 저감화 정책과 사업을 펼치고 있다. 많은 국가들은 식 품산업에서 나트륨 함량을 줄일 수 있는 방안을 마련하는 한 편, 나트륨 저감화에 대한 소비자의 인식을 제고하기 위한 교 육 매체와 도구를 개발하여 메시지를 전달하고자 노력하고 있다 [9-11]. 유럽, 미국, 캐나다 등은 다양한 매체와 캠페 인을 통해 소비자의 행동변화를 가져올 수 있도록 각종 분야 에서 지원을 구축하고 있다 $[9,10,12,13]$. 우리나라에서 는 제 3 차 국민건강진흥종합계획 [14]에서 나트륨 저감화 정 책이 제시되었다. 식품의약품안전처에서 '나트륨 줄이기 국 민운동본부'를 출범시켜 가공식품회사와 급식 및 외식산업 분야에서 나트륨 저감화를 실천할 수 있도록 하고 교육 · 홍 보와 캠페인을 통해 국민의 인식을 제고하기 위한 노력을 하 고 있다[15]. 서울시에서는 서울시 나트륨 섭취 저감화 종 합대책 2020'[11]을 수립하여 시민들의 나트륨 인식 제고 와 나트륨 섭취량을 감소시키고 조리종사자들의 나트륨 줄 이기 필요성 인식을 높이고자 하였다.

식품의약품안전처는 2014년부터 성인 단체급식 이용자 의 중식을 통한 나트륨 섭취 감소를 위해 나트륨 $1,300 \mathrm{mg}$ 이하의 급식을 제공하는 ‘삼삼급식소'의 운영을 유지 · 확대
할 수 있도록 지자체와 단체급식소의 참여를 적극적으로 유 도하고 있다 $[16,17]$. ‘삼삼급식소'는 운영 - 관리 지침에 따라 1 개월 이상 사전운영 후, 지방자치단체의 평가를 받아 지정되고 있다[16]. 단체급식소의 경우 이용 고객들의 참여 가 없이는 나트륨을 줄인 급식 제공이 매우 어려우므로, 고객 들의 나트륨 저감화 및 저나트륨 식단에 대한 인식 향상과 필 요성 요구가 중요하다. 영양사들이 저나트륨 식단 제공의 필 요성을 공감하고 나트륨 저감 급식소 운영에 대한 의지가 높 다고 하더라도 저나트륨 식단 제공에 대한 고객의 불만이 많 아지면 지속적인 운영이 어려워진다.

저나트륨 식단 제공을 위한 삼삼급식소 운영의 유지 · 확 대를 위해서는 나트륨 저감 급식 제공의 대상자인 직장 단체 급식 이용 고객들의 나트륨 저감 급식 운영에 대한 인식조사 가 필요하다. 또한 나트륨 저감 급식 인식에 영향을 미치는 요인을 분석하여, 나트륨 관련 교육 · 홍보 및 캠페인을 수행 할 때 기초자료로 활용할 수 있도록 해야 한다. 그러나 지금 까지 국내에서 수행된 나트륨 관련 인식조사 연구는 초등학 생 [18], 여대생 [19] 및 성인 [20], 노인 [21], 초등학교 교 사 [22]를 대상으로 진행되었고, 급식 이용 성인을 대상으로 한 나트륨 저감 급식에 대한 인식조사는 거의 이루어지지 못 하였다. 따라서 본 연구에서는 산업체 급식소 고객이 인지하 는 나트륨 저감 급식소 운영현황, 나트륨 저감 급식 운영 필 요성 인식, 저나트륨 식단 인식, 건강관심도를 조사하고, 고 객의 건강관심도가 나트륨 저감 급식 운영 필요성 인식과 저 나트륨 식단 인식에 미치는 영향을 분석하였다.

\section{연구내용 및 방법}

\section{1. 조사대상자 및 기간}

산업체 급식 고객의 나트륨 저감 급식 인식조사를 위하여 직장 급식소 이용자를 대상으로 편의표본추출법을 이용하여 설문을 실시하였다. 설문조사는 온라인설문 전문기관에 의 뢰하여 진행하였고, 2019년 9월 3일부터 10일까지 실시하 였다. 설문 전문기관에 등록된 패널 중에서 서울에 거주하고 있는 직장 급식소 이용 20 50대 고객 340명을 대상으로 온라인설문을 요청하였다. 본 연구는 대전대학교 생명윤리 심의위원회 (Approval Number: 1040647-201908HR-002-02)의 승인을 받아 수행되었다.

\section{2. 조사내용}

설문은 산업체 급식소 이용 고객이 인식하는 급식소의 나 트륨 저감 운영현황, 나트륨 저감 급식 운영 필요성, 저나트 륨 식단 인식, 직장 급식소 이용 고객의 건강관심도 및 일반 
사항으로 구성되었다 [7, 23-27]. 설문은 직장 급식소 이용 고객의 일반사항 6 문항, 고객의 건강관심도 5 문항, 급식소 의 나트륨 저감 운영 5 문항, 나트륨 저감 급식 운영 필요성 10 문항, 저나트륨 식단 인식 7문항으로 구성하였다. 나트륨 저감 급식소 필요성, 저나트륨 식단 인식, 응답자의 건강관 심도는 5점 척도 (1:전혀 그렇지 않다-5:매우 그렇다)로 평 가하였고, 급식소의 나트륨 저감 운영에서는 염도 게시 여 부, 나트륨 저감 급식 제공, 급식의 간. 나트륨 저감 관련 교 육 · 홍보 및 컨텐츠 내용을 선택문항으로 조사하였다.

\section{3. 자료 분석}

수집된 자료는 IBM SPSS Statistics 24.0 (IBM Corporation, Armonk, NY, USA)을 이용하여 분석하였다. 산 업체 급식소 이용 고객의 일반사항과 급식소의 나트륨 저감
운영은 빈도 및 백분율을 구하고, 고객의 건강관심도, 나트 륨 저감 급식 운영 필요성, 저나트륨 식단 인식은 평균과 표 준편차를 계산하였다. 측정 항목의 연령별 차이를 보기 위해 서 교차분석, Fisher's exact test, ANOVA 분석을 실시하 였고, LSD로 사후검정하였으며, $P<0.05$ 수준에서 유의성 을 검증하였다. 측정 항목들의 간의 연관성 측정을 위해 상 관분석과 단순회귀분석을 실시하였다.

\section{결 과}

\section{1. 응답자의 일반사항과 건강관심도}

설문지 응답자 340명의 일반사항에 대한 빈도분석 결과 를 Table 1에 제시하였다. 응답자는 서울거주 20 50대 직 장 급식소 이용 고객을 대상으로 하였고 20대, 30대, 40대,

Table 1. General characteristics and health concerns of respondents

\begin{tabular}{|c|c|c|c|c|c|c|c|}
\hline \multirow{2}{*}{ Variables } & & \multirow{2}{*}{$\begin{array}{c}\text { Total } \\
(n=340)\end{array}$} & \multicolumn{4}{|c|}{ Age } & \multirow{2}{*}{$\begin{array}{l}\chi^{2} \text { or } \\
\text { F-value }\end{array}$} \\
\hline & & & $\begin{array}{c}20 s \\
(n=85)\end{array}$ & $\begin{array}{c}30 s \\
(n=85)\end{array}$ & $\begin{array}{c}40 s \\
(n=85)\end{array}$ & $\begin{array}{c}50 s \\
(n=85)\end{array}$ & \\
\hline \multirow[t]{2}{*}{ Gender } & Male & $186(54.7)$ & $40(47.1)$ & $47(55.3)$ & $50(58.8)$ & $49(57.6)$ & 2.896 \\
\hline & Female & $154(45.3)$ & $45(52.9)$ & $38(44.7)$ & $35(41.2)$ & $36(42.4)$ & \\
\hline \multirow{4}{*}{$\begin{array}{l}\text { Educational } \\
\text { level }\end{array}$} & High school & $30(8.8)$ & $8(9.4)$ & $3(3.5)$ & $7(8.2)$ & $12(14.1)$ & $20.130 *$ \\
\hline & College degree & $50(14.7)$ & $18(21.2)$ & $13(15.3)$ & $8(9.4)$ & $11(12.9)$ & \\
\hline & Undergraduate degree & $210(61.8)$ & $49(57.6)$ & $63(74.1)$ & $52(61.2)$ & $46(54.1)$ & \\
\hline & Graduate degree & 50 (14.7) & $10(11.8)$ & $6(7.1)$ & $18(21.2)$ & $16(18.8)$ & \\
\hline \multirow[t]{5}{*}{ Work place } & Office & $262(77.1)$ & $69(81.2)$ & $72(84.7)$ & $67(78.8)$ & $54(63.5)$ & $38.779 * * * 21$ \\
\hline & Hospital & $29(8.5)$ & $7(8.2)$ & $4(4.7)$ & $13(15.3)$ & $5(5.9)$ & \\
\hline & Factory & $16(4.7)$ & $1(1.2)$ & $2(2.4)$ & $4(4.7)$ & $9(10.6)$ & \\
\hline & Sales or service & $12(3.5)$ & $1(1.2)$ & $3(3.5)$ & $0(0.0)$ & $8(9.4)$ & \\
\hline & Others & $21(6.2)$ & $7(8.2)$ & $4(4.7)$ & $1(1.2)$ & $9(10.6)$ & \\
\hline \multirow{2}{*}{$\begin{array}{l}\text { Foodservice } \\
\text { operation type }\end{array}$} & Self-operated & $117(34.4)$ & $25(29.4)$ & $26(30.6)$ & $25(29.4)$ & $41(48.2)$ & $9.630 *$ \\
\hline & Contracted & $223(65.6)$ & $60(70.6)$ & $59(69.4)$ & $60(70.6)$ & $44(51.8)$ & \\
\hline \multirow{5}{*}{$\begin{array}{l}\text { Frequency of } \\
\text { use per week } \\
\text { (Lunch) }\end{array}$} & Once & $23(6.8)$ & $9(10.6)$ & $7(8.2)$ & $2(2.4)$ & $5(5.9)$ & 20.379 \\
\hline & 2 times & $30(8.8)$ & $13(15.3)$ & $7(8.2)$ & $6(7.1)$ & $4(4.7)$ & \\
\hline & 3 times & $66(19.4)$ & $16(18.8)$ & $17(20.0)$ & $22(35.9)$ & $11(12.9)$ & \\
\hline & 4 times & $78(22.9)$ & $19(22.4)$ & $17(20.0)$ & $23(27.1)$ & $19(22.4)$ & \\
\hline & 5 times & $143(42.1)$ & $28(32.9)$ & $37(43.5)$ & $32(37.6)$ & $46(54.1)$ & \\
\hline \multirow{3}{*}{$\begin{array}{l}\text { Frequency of } \\
\text { use per day }\end{array}$} & Once & $295(86.8)$ & $72(84.7)$ & $78(91.8)$ & $70(82.4)$ & 75 (88.2) & $5.409^{3)}$ \\
\hline & 2 times & $34(10.0)$ & $10(11.8)$ & $6(7.1)$ & $12(14.1)$ & $6(7.1)$ & \\
\hline & 3 times & $11(3.2)$ & $3(3.5)$ & $1(1.2)$ & $3(3.5)$ & $4(4.7)$ & \\
\hline \multirow{5}{*}{ Heath concerns } & $\begin{array}{l}\text { I choose health food for } \\
\text { my health'). }\end{array}$ & $3.52 \pm 0.94$ & $3.54 \pm 1.13$ & $3.34 \pm 0.96$ & $3.65 \pm 0.87$ & $3.55 \pm 0.73$ & 1.615 \\
\hline & I have regular checkups. & $3.54 \pm 0.90$ & $3.00^{b} \pm 1.06$ & $3.51^{a} \pm 0.83$ & $3.78^{a} \pm 0.78$ & $3.87^{a} \pm 0.63$ & $18.507 * * *$ \\
\hline & $\begin{array}{l}\text { I look for books or } \\
\text { information for health. }\end{array}$ & $3.02 \pm 1.01$ & $2.95^{a} \pm 1.27$ & $2.80^{a} \pm 1.02$ & $3.13^{b} \pm 0.87$ & $3.21^{b} \pm 0.76$ & $2.886^{*}$ \\
\hline & I am interested in health. & $3.56 \pm 0.81$ & $3.51 \pm 0.90$ & $3.42 \pm 0.85$ & $3.65 \pm 0.81$ & $3.67 \pm 0.81$ & 1.788 \\
\hline & $\begin{array}{l}\text { I exercise regularly for good } \\
\text { health. }\end{array}$ & $3.39 \pm 1.07$ & $3.54 \pm 1.20$ & $3.15 \pm 1.12$ & $3.39 \pm 0.99$ & $3.46 \pm 0.93$ & 2.089 \\
\hline
\end{tabular}

$\mathrm{n}(\%)$ or Mean $\pm \mathrm{SD}, * P<0.05, * * * P<0.001$

Means with different superscripts are significantly different at the alpha $=0.05$ by LSD post-hoc test.

1) A 5-point scale was used (1: strongly disagree $\sim 5$ : strongly agree).

2) $P<0.001$ by Fisher's exact test

3) $P=0.489$ by Fisher's exact test 
50 대가 각각 $25.0 \%$ (85명)로 구성되었다. 학력의 경우는 4 년제 대학 졸업자가 $61.8 \%$ 로 가장 많았고, 다음으로는 2년 제 대학과 대학원 졸업자가 $14.7 \%$ 를 차지하였으며, 연령대 별로 차이가 있는 것으로 나타났다 $(P<0.05)$. 응답자는 사 무직이 $77.1 \%$ 로 가장 많은 비중을 차지하였고, 연령별 차이 가 있는 것으로 조사되었다 $(P<0.001)$. 이용하는 급식소 의 운영체제는 위탁급식소가 $65.6 \%$ 였고, 연령별 차이가 있 는 것으로 나타났다 $(P<0.05)$. 점심 급식의 주당 이용횟수 는 5 회 이용자가 $42.1 \%$ 로 가장 높은 비율을 보였고, 전 연 령 모두 5 회 이용자가 가장 많은 것으로 나타났다. 하루 급 식의 이용횟수는 1 회 이용자가 $86.8 \%$ 로 가장 높은 것으로 조사되었고, 전 연령대에서 1 회 이용자가 가장 많았고 연령 대별 차이는 나타나지 않았다.

급식소 이용 고객의 건강관심도는 ‘나는 건강에 관심이 많
다'가 3.56점 (5점 만점)으로 가장 높은 점수를 보였다. 다 음으로는 '나는 정기적으로 건강검진을 받고 있다'가 3.54 점으로 조사되었으며, 20 대의 점수가 3.00점을 보여 다른 연령대보다 유의적으로 낮은 점수를 보였다 $(P<0.05)$. '나 는 건강을 위해 건강식품을 구입한다'가 3.52 점, '나는 건강 을 위해 정기적으로 운동한다'가 3.39점을 보였으며 연령대 별 차이는 없는 것으로 조사되었다. '나는 건강 관련 서적이 나 정보를 찾아본다, 항목은 3.02점으로 가장 낮은 점수를 보였고, 20 30대와 40 50대 연령에 따른 차이를 보였다 $(P<0.05)$.

\section{2. 산업체 급식소의 나트륨 저감 운영현황}

응답자가 이용하는 산업체 급식소의 나트륨 저감 운영현 황은 Table 2에 제시하였다. 나트륨을 줄인 식단을 전혀 제

Table 2. General characteristics of foodservice

\begin{tabular}{|c|c|c|c|c|c|c|c|}
\hline \multirow{2}{*}{ Variables } & & \multirow[b]{2}{*}{$\begin{array}{c}\text { Total } \\
(n=340)\end{array}$} & \multicolumn{4}{|c|}{ Age } & \multirow[b]{2}{*}{$\chi^{2}$} \\
\hline & & & $\begin{array}{c}20 s \\
(n=85)\end{array}$ & $\begin{array}{c}30 s \\
(n=85)\end{array}$ & $\begin{array}{c}40 s \\
(n=85)\end{array}$ & $\begin{array}{c}50 s \\
(n=85)\end{array}$ & \\
\hline \multirow{6}{*}{$\begin{array}{l}\text { Serving low } \\
\text { sodium diets }\end{array}$} & None & $176(51.8)$ & $54(63.5)$ & $48(56.5)$ & $42(49.4)$ & $32(37.6)$ & \multirow[t]{6}{*}{22.568} \\
\hline & Everyday & 55 (16.2) & $10(11.8)$ & $10(11.8)$ & $16(18.8)$ & $19(22.4)$ & \\
\hline & Daily selection & $25(7.4)$ & $4(4.7)$ & $3(3.5)$ & $7(8.2)$ & $11(12.9)$ & \\
\hline & Regularly & $30(8.8)$ & $6(7.1)$ & $9(10.6)$ & $7(8.2)$ & $8(9.4)$ & \\
\hline & Sometimes & $47(13.8)$ & $10(11.8)$ & $15(17.6)$ & $10(11.8)$ & $12(14.1)$ & \\
\hline & Others & $7(2.1)$ & $1(1.2)$ & $0(0.0)$ & $3(3.5)$ & $3(3.5)$ & \\
\hline \multirow{5}{*}{$\begin{array}{l}\text { Salinity posting of } \\
\text { kimchi or soup }\end{array}$} & None & $173(50.9)$ & $39(45.9)$ & $50(58.8)$ & $40(47.1)$ & $44(51.8)$ & \multirow[t]{5}{*}{$14.992^{1)}$} \\
\hline & Once twice/month & $36(10.6)$ & $8(9.4)$ & $6(7.1)$ & $10(11.8)$ & $12(14.1)$ & \\
\hline & $3 \sim 4$ times/month & $23(6.8)$ & $11(12.9)$ & $5(5.9)$ & $3(3.5)$ & $23(4.7)$ & \\
\hline & 2 3 times/week & $14(4.1)$ & $4(4.7)$ & $3(3.5)$ & $6(7.1)$ & $1(1.2)$ & \\
\hline & 4 5 times/week & $94(27.6)$ & $23(27.1)$ & $21(24.7)$ & $26(30.6)$ & $24(28.2)$ & \\
\hline \multirow{5}{*}{$\begin{array}{l}\text { Perception the } \\
\text { saltiness of } \\
\text { foodservice } \\
\text { meals }\end{array}$} & Very salty & $2(0.6)$ & $0(0.0)$ & $0(0.0)$ & $1(1.2)$ & $1(1.2)$ & \multirow[t]{5}{*}{$13.912^{2)}$} \\
\hline & Salty & $73(21.5)$ & $18(21.2)$ & $22(25.9)$ & $22(25.9)$ & $11(12.9)$ & \\
\hline & Moderate & $229(67.4)$ & $62(72.9)$ & $54(63.5)$ & $52(61.2)$ & $61(71.8)$ & \\
\hline & Unsalty & $35(10.3)$ & $5(5.9)$ & $8(9.4)$ & $10(11.8)$ & $12(14.1)$ & \\
\hline & Very unsalty & $1(0.3)$ & $0(0.0)$ & $1(0.0)$ & $0(0.0)$ & $0(0.0)$ & \\
\hline \multirow{4}{*}{$\begin{array}{l}\text { Education and } \\
\text { promotion of } \\
\text { the sodium } \\
\text { reduction }\end{array}$} & None & $237(69.7)$ & $57(67.1)$ & $65(76.5)$ & $60(70.6)$ & $55(64.7)$ & \multirow[t]{4}{*}{$7.533^{3)}$} \\
\hline & Once -twice/3 months & $81(23.8)$ & $21(24.7)$ & $17(20.0)$ & $18(21.2)$ & $25(29.4)$ & \\
\hline & 3 4 times/3 months & $16(4.7)$ & $6(7.1)$ & $1(1.2)$ & $5(5.9)$ & $4(4.7)$ & \\
\hline & $5 \sim 6$ times/3 months & $6(1.8)$ & $1(1.2)$ & $2(2.4)$ & $2(2.4)$ & $1(1.2)$ & \\
\hline \multirow{5}{*}{$\begin{array}{l}\text { Contents of } \\
\text { education and } \\
\text { promotion of } \\
\text { the sodium } \\
\text { reduction }\end{array}$} & $\begin{array}{l}\text { Relationship between Sodium and blood } \\
\text { pressure }\end{array}$ & $20(19.4)$ & $5(17.9)$ & $3(15.0)$ & $1(4.0)$ & $11(36.7)$ & \multirow[t]{5}{*}{$27.928 * * 4$} \\
\hline & $\begin{array}{l}\text { Relationship between Sodium and } \\
\text { Disease }\end{array}$ & $32(31.1)$ & $3(10.7)$ & $8(40.0)$ & $12(48.0)$ & $9(30.0)$ & \\
\hline & Cooking methods to reduce sodium & $19(18.4)$ & $9(32.1)$ & $1(5.0)$ & $4(16.0)$ & $5(16.7)$ & \\
\hline & Method to choose low sodium food & $5(4.9)$ & $0(0.0)$ & $3(15.0)$ & $2(8.0)$ & $0(0.0)$ & \\
\hline & Sodium content in food & $27(26.2)$ & $11(39.3)$ & $5(25.0)$ & $6(24.0)$ & $5(16.7)$ & \\
\hline
\end{tabular}

$\mathrm{n}(\%), * * P<0.01$

1) $P=0.259$ by Fisher's exact test

2) $P=0.248$ by Fisher's exact test

3) $P=0.568$ by Fisher's exact test

4) $P=0.002$ by Fisher's exact test 
공하지 않는 급식소가 $51.8 \%$ 였고, 매일 모든 메뉴를 저염으 로 제공하는 급식소가 $16.2 \%$, 가끔 저염 메뉴를 제공하는 급식소가 $13.8 \%$ 로 조사되었다. 이용 급식소의 김치 및 국의 염도 표시 여부는 $50.9 \%$ 가 게시하지 않는다고 하였으며, 주 4 5회가 $27.6 \%$ 로 조사되었다. 응답자의 식단에 대한 간의 평가는 ‘보통이다’라고 응답한 고객은 $67.4 \%$ 로 가장 많았 고, ‘짜다’라고 응답한 고객은 $21.5 \%$ 였으며 연령별로 차이 는 없었다. 나트륨 저감화에 대한 교육 - 홍보는 $69.7 \%$ 가 제 공받은 적이 없는 것으로 응답하였다. 제공받은 나트륨 저감 화에 대한 교육 · 홍보 콘텐츠에서는 '나트륨과 질병 관계' $31.1 \%$, '식품의 나트륨 함량' $26.2 \%$, '나트륨과 혈압 관계' $19.4 \%$, '나트륨 저감 조리방법' $18.4 \%$ 순으로 인식하고 있 었고, 연령별 인식에 차이가 있는 것으로 분석되었다 $(P<0.01)$.

\section{3. 나트륨 저감 급식 운영 방안의 요구도 인식}

급식소 이용 고객이 인식하는 나트륨 저감 급식소 운영 필 요성은 Table 3에 제시하였다. '나트륨 섭취를 줄이기 위해 양념 및 소스류를 따로 제공할 필요가 있다'가 3.88점 (5점
만점)으로 가장 점수가 높은 것으로 조사되었고, 다음으로 ‘저나트륨 식단을 제공할 필요가 있다'가 3.87점으로 나타 났다. '나트륨 섭취를 줄이기 위해 ‘국 없는 날'을 시행할 필 요가 있다'가 3.14점으로 가장 낮은 점수를 보였으며 30대 의 점수가 2.80점으로 가장 낮은 점수를 보여 연령대별 차 이가 있는 것으로 조사되었다 $(P<0.01)$. 다음으로 낮은 점 수를 보인 항목은 '나트륨 섭취를 줄이기 위해 저염 가공식 픔을 제공할 필요가 있다’가 3.19점을 보였고 20 30대보 다 40 50대의 점수가 더 높은 것으로 나타났다 $(P<0.05)$. '건강을 위해 급식은 심심하게 조리해야 한다'의 항목은 3.71 점을 보였고, 50 대의 점수가 다른 연령대에 비하여 유의적 으로 점수가 높은 것으로 조사되었다 $(P<0.05)$. '나트륨 섭 취를 줄이기 위해 국이나 찌개의 양을 줄일 필요가 있다'는 3.39점이었고, 30대에서 3.12점을 보여 다른 연령대보다 유의적으로 낮았다 $(P<0.05)$.

\section{4. 급식소의 저나트륨 식단에 대한 인식}

급식소 이용 고객의 저나트륨 식단 제공에 대한 인식은 Table 4에 제시하였다. 급식소의 저나트륨 식단에 대한 인

Table 3. Customers' perception of needs on sodium-reduced operation in foodservice

\begin{tabular}{|c|c|c|c|c|c|c|}
\hline \multirow[b]{2}{*}{ Variables } & \multirow{2}{*}{$\begin{array}{c}\text { Total } \\
(n=340)\end{array}$} & \multicolumn{4}{|c|}{ Age } & \multirow[b]{2}{*}{ F-value } \\
\hline & & $\begin{array}{c}20 s \\
(n=85)\end{array}$ & $\begin{array}{c}30 s \\
(n=85)\end{array}$ & $\begin{array}{c}40 s \\
(n=85)\end{array}$ & $\begin{array}{c}50 s \\
(n=85)\end{array}$ & \\
\hline 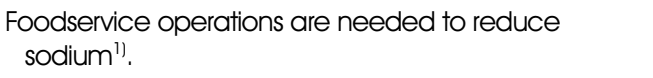 & $3.82 \pm 0.67$ & $3.79 \pm 0.80$ & $3.86 \pm 0.62$ & $3.78 \pm 0.64$ & $3.87 \pm 0.61$ & 0.431 \\
\hline $\begin{array}{l}\text { It is necessary for foodservices to provide low sodium } \\
\text { diets. }\end{array}$ & $3.87 \pm 0.76$ & $3.80 \pm 0.87$ & $3.82 \pm 0.69$ & $3.88 \pm 0.82$ & $3.99 \pm 0.63$ & 1.039 \\
\hline $\begin{array}{l}\text { Foodservice should prepare a low sodium diet for } \\
\text { good health. }\end{array}$ & $3.71 \pm 0.84$ & $3.60^{a} \pm 0.93$ & $3.55^{a} \pm 0.88$ & $3.72^{a} \pm 0.75$ & $3.98^{b} \pm 0.76$ & $4.413 * *$ \\
\hline $\begin{array}{l}\text { Foodservice should provide a way to consume less } \\
\text { sodium. }\end{array}$ & $3.77 \pm 0.72$ & $3.79 \pm 0.76$ & $3.76 \pm 0.77$ & $3.71 \pm 0.70$ & $3.84 \pm 0.67$ & 0.468 \\
\hline $\begin{array}{l}\text { Foodservice should provide education and } \\
\text { promotional materials on overall dietary practices to } \\
\text { reduce sodium intake. }\end{array}$ & $3.71 \pm 0.75$ & $3.59 \pm 0.90$ & $3.65 \pm 0.77$ & $3.75 \pm 0.65$ & $3.84 \pm 0.61$ & 1.861 \\
\hline $\begin{array}{l}\text { Foodservice should operate a "day without soup" to } \\
\text { reduce sodium intake. }\end{array}$ & $3.14 \pm 1.04$ & $3.25^{b} \pm 1.06$ & $2.80^{a} \pm 1.17$ & $3.22^{b} \pm 0.99$ & $3.28^{b} \pm 0.87$ & $4.156 * *$ \\
\hline $\begin{array}{l}\text { Foodservice should reduce the amount of soup or } \\
\text { stew to reduce sodium intake. }\end{array}$ & $3.39 \pm 0.92$ & $3.45^{b} \pm 0.99$ & $3.12^{a} \pm 0.98$ & $3.46^{b} \pm 084$ & $3.54^{b} \pm 0.81$ & $3.596 *$ \\
\hline $\begin{array}{l}\text { To reduce sodium intake, foodservices should provide } \\
\text { more raw vegetables than kimchi. }\end{array}$ & $3.36 \pm 0.89$ & $3.28 \pm 1.04$ & $3.24 \pm 0.87$ & $3.51 \pm 0.80$ & $3.42 \pm 0.82$ & 1.687 \\
\hline $\begin{array}{l}\text { Foodservice should provide separate spices and } \\
\text { sauces to reduce sodium intake. }\end{array}$ & $3.88 \pm 0.83$ & $4.04 \pm 0.94$ & $3.93 \pm 0.67$ & $3.71 \pm 0.86$ & $3.85 \pm 0.82$ & 2.387 \\
\hline $\begin{array}{l}\text { In order to reduce sodium intake, foodservices should } \\
\text { supply low sodium processed foods. }\end{array}$ & $3.19 \pm 0.97$ & $2.93^{a} \pm 0.94$ & $2.99^{a} \pm 1.03$ & $3.35^{b} \pm 0.97$ & $3.47^{b} \pm 0.85$ & $6.714 * * *$ \\
\hline
\end{tabular}

Mean $\pm \mathrm{SD}, * P<0.05, * * P<0.01, * * * P<0.001$

Means with different superscripts are significantly different at the alpha $=0.05$ by LSD post-hoc test.

1) A 5-point scale was used (1: strongly disagree $\sim 5$ : strongly agree). 
26 - 나트륨 저감화의 운영 및 필요성에 대한 인식

Table 4. Customers' perception of low sodium diets provided by foodservice

\begin{tabular}{|c|c|c|c|c|c|c|}
\hline \multirow[b]{2}{*}{ Variables } & \multirow{2}{*}{$\begin{array}{c}\text { Total } \\
(n=340)\end{array}$} & \multicolumn{4}{|c|}{ Age } & \multirow[b]{2}{*}{ F-value } \\
\hline & & $\begin{array}{c}20 s \\
(n=85)\end{array}$ & $\begin{array}{c}30 s \\
(n=85)\end{array}$ & $\begin{array}{c}40 s \\
(n=85)\end{array}$ & $\begin{array}{c}50 s \\
(n=85)\end{array}$ & \\
\hline A low sodium diet is necessary in foodservice ${ }^{11}$. & $3.79 \pm 0.77$ & $3.79^{a} \pm 0.80$ & $3.76^{a} \pm 081$ & $3.62^{a} \pm 0.83$ & $4.00^{b} \pm 0.58$ & $3.526 *$ \\
\hline $\begin{array}{l}\text { A low sodium diet is good for my health in } \\
\text { foodservice. }\end{array}$ & $4.13 \pm 0.67$ & $4.13 \pm 0.77$ & $4.08 \pm 0.64$ & $4.04 \pm 0.65$ & $4.27 \pm 0.61$ & 1.972 \\
\hline $\begin{array}{l}\text { A low sodium diet will help improve the quality of } \\
\text { the foodservice. }\end{array}$ & $3.46 \pm 0.85$ & $3.41 \pm 0.92$ & $3.46 \pm 0.98$ & $3.44 \pm 0.76$ & $3.55 \pm 0.73$ & 0.445 \\
\hline A low sodium diet increases trust in foodservice. & $3.66 \pm 0.78$ & $3.76 \pm 0.78$ & $3.56 \pm 0.84$ & $3.58 \pm 0.84$ & $3.75 \pm 0.65$ & 1.654 \\
\hline $\begin{array}{l}\text { A low sodium diet uses less processed food in } \\
\text { foodservice. }\end{array}$ & $3.57 \pm 0.82$ & $3.58 \pm 0.97$ & $3.53 \pm 0.87$ & $3.53 \pm 0.70$ & $3.66 \pm 0.70$ & 0.475 \\
\hline $\begin{array}{l}\text { When a low sodium diet is available, I think a new } \\
\text { recipe has been developed. }\end{array}$ & $3.52 \pm 0.83$ & $3.53 \pm 0.89$ & $3.46 \pm 0.84$ & $3.47 \pm 0.73$ & $3.62 \pm 0.83$ & 0.705 \\
\hline A low sodium diet is nutritionally superior. & $3.61 \pm 0.76$ & $3.86^{\mathrm{b}} \pm 0.77$ & $3.58^{a} \pm 0.78$ & $3.40^{a} \pm 0.73$ & $3.62^{a} \pm 0.71$ & $5.447 * * *$ \\
\hline
\end{tabular}

Mean $\pm \mathrm{SD}, * P<0.05, * * * P<0.001$

Means with different superscripts are significantly different at the alpha $=0.05$ by LSD post-hoc test.

1) A 5-point scale was used (1: strongly disagree $\sim 5$ : strongly agree).

식은 ‘급식소의 저나트륨 식단은 건강에 도움이 된다'가 4.13 점으로 가장 높은 점수를 보였고 연령별 차이는 없는 것으로 조사되었다. 다음으로는 ‘급식소의 저나트륨 식단은 나의 식 생활 개선에 중요한 역할을 한다, 항목으로 3.79점을 보였 고, 50대에서 4.00점으로 가장 높은 점수를 보여 다른 연령 대보다 유의적으로 높은 점수를 나타냈다 $(P<0.05)$. '저나 트륨 식단 제공은 급식소의 신뢰를 증가 시킨다, 항목은 3.66 점을 보였고, 연령에 따른 차이는 보이지 않았다. ‘급식소의 저나트륨 식단은 영양적으로 우수하다, 항목은 3.61점을 보 였고, 20대에서 3.86점을 보여 다른 연령대보다 유의적으로 높은 점수를 나타냈다 $(P<0.05)$.

\section{5. 건강관심도가 나트륨 저감 급식 운영 필요성과 저나트륨 식단 인식에 미치는 영향}

산업체 급식소 고객의 건강관심도, 나트륨 저감 급식 운영 필요성 인식, 저나트륨 식단 인식의 상관관계를 분석하였다 (Table 5). 건강관심도는 나트륨 저감 급식 운영 필요성 인 식 $(P<0.01)$, 저나트륨 식단 인식 $(P<0.01)$ 과 상관관계
가 있는 것으로 나타났고, 나트륨 저감 급식 운영의 필요성 인식과 저나트륨 식단에 대한 인식 사이 $(P<0.01)$ 에 관련 성이 있는 것으로 분석되었다.

급식소 이용 고객의 건강관심도와 나트륨 저감 급식 운영 필요성 및 저나트륨 식단 관련 인식의 관계를 분석한 단순회 귀 분석을 Table 6에 제시하였다. 고객의 '건강관심도'를 독 립변수로, 종속변수는 '나트륨 저감 급식 운영 필요성'으로 설정하여 단순회귀분석을 실시하였다. '건강관심도'와 '나트 름 저감 급식 운영 필요성 인식, 관계의 회귀모형 $F-$ value 가 29.561 $(P<0.001)$ 이고 회귀식에 대한 설명력은 $8.0 \%$ 였다. 독립변수인 '건강관심도 ( $\beta=0.284, P<0.001)$ '는 종속변수인 '나트륨 저감 급식 운영 필요성 인식'에 정 $(+)$ 의 영향을 미치는 것으로 조사 되었다. '건강관심도'와 '저나 트륨 식단 인식, 관계의 회귀모형 $F$-value가 $57.320(P<$ 0.001)이고 회귀식에 대한 설명력은 $14.5 \%$ (0.145)였다. 독립변수인 '건강관심도 $(\beta=0.381, P<0.001)$ '는 종속 변수인 '저나트륨 식단 인식'에 정 $(+)$ 의 영향을 미치는 것 으로 조사 되었다.

Table 5. Correlation relationship between main variables

\begin{tabular}{lccc}
\hline Variables & $\begin{array}{c}\text { Health } \\
\text { concerns }\end{array}$ & $\begin{array}{c}\text { Perception of need } \\
\text { for sodium-reduced } \\
\text { operation in foodservice }\end{array}$ & $\begin{array}{c}\text { Perception of low } \\
\text { sodium diets in } \\
\text { foodservice }\end{array}$ \\
\hline Health concerns & 1 & 1 & $0.624^{* *}$ \\
Perception of need for sodium-reduced operation in foodservice & $0.284^{* *}$ & $0.381^{* *}$ & 1 \\
Perception of low sodium diets in foodservice & & 1 \\
\hline
\end{tabular}

** $P<0.01$ 
Table 6. Effects of customers' health concerns on perceptions of the need for sodium-reduced operation and of low sodium diets in foodservice

\begin{tabular}{|c|c|c|c|c|c|}
\hline \multirow{2}{*}{$\begin{array}{l}\text { Independent } \\
\text { variables }\end{array}$} & \multirow{2}{*}{$\begin{array}{l}\text { Dependent } \\
\text { variables }\end{array}$} & \multicolumn{2}{|c|}{$\begin{array}{l}\text { Unstandardized } \\
\text { coefficients }\end{array}$} & \multirow{2}{*}{$\begin{array}{c}\text { Standardized } \\
\text { coefficients }\end{array}$} & \multirow{2}{*}{ t-value } \\
\hline & & B & S.E & & \\
\hline \multirow{6}{*}{ Health concerns } & Constant & 2.793 & 0.148 & & $18.870 * * *$ \\
\hline & $\begin{array}{l}\text { Perception of need for sodium-reduced } \\
\text { operation in foodservice }\end{array}$ & 0.239 & 0.044 & 0.284 & $5.437 * * *$ \\
\hline & \multicolumn{5}{|c|}{$R^{2}=0.080$, Adjusted $R^{2}=0.078, F=29.561 * * *$} \\
\hline & Constant & 2.549 & 0.152 & & $16.778 * * *$ \\
\hline & Perception of low sodium diets in foodservice & 0.342 & 0.045 & 0.381 & $7.571 * * *$ \\
\hline & \multicolumn{5}{|c|}{$R^{2}=0.145$, Adjusted $R^{2}=0.142, F=57.320 * * *$} \\
\hline
\end{tabular}

*** $P<0.001$

\section{고 찰}

산업체 급식소 고객의 나트륨 저감에 관련한 인식조사와 인식에 영향을 미치는 요인을 파악하는 것은 급식소의 나트 륨 저감화 운영 전략에 중요한 근거 자료가 된다. 식품의약 품안전처에서는 '삼삼급식소' 운영 확대를 위해 노력하고 있 고 급식소 대상 나트륨 저감화 시범사업을 실시하며 저나트 륨 식사 제공을 권장하고 있다[28]. 응답자 $51.8 \%$ 는 저나 트륨 식사를 제공 받은 적이 없다고 응답하였다. 이는 산업 체 급식소의 실제 나트륨 저감화 실천 여부가 아니라, 고객 들의 급식소 나트륨 저감 운영에 대한 인식으로 실제 급식소 의 나트륨 저감화 실천과는 차이가 있을 수 있다. 응답자의 $50.9 \%$ 의 직장인들이 이용 급식소는 염도 게시를 하지 않고 있다고 응답하였으며, 주 4 5회를 게시한다고 응답한 직장 인은 $27.6 \%$ 로 조사되었다. 학교급식 영양사들을 대상으로 조사한 Lee [29]의 연구에서는 염도계 보유 비율이 $86.6 \%$ 로 나타났고, 국이나 찌개류의 염도를 공지하는 비율이 $15.4 \%$ 로 낮았으며, 한 끼 식단의 나트륨 함량 공지비율은 $12.6 \%$ 로 낮았다. 산업체 급식 고객들을 대상으로 한 Yoon \& Kang [27]의 연구에서는 제공 식단에 대한 음식의 간에 대 한 조사결과, ‘보통이다’가 $60.2 \%$ 로 가장 높았고, 다음은 ‘싱겁다'가 $25.2 \%$, ‘짜다’가 $11.4 \%$ 로 나타났다. 본 연구에 서는 '보통이다'가 $67.4 \%$, '짜다'가 $21.5 \%$, '싱겁다'가 $10.3 \%$ 로 나타나 Yoon \& Kang [27]의 결과처럼 보통이라 고 인지하는 응답자가 가장 많았지만 '짜다'고 응답한 고객 이 '싱겁다'고 응답한 고객보다 더 많아 다소 다른 결과를 보 였다.

식품의약품안전처에서는 산업체 급식소에서의 나트륨 줄 이기 관련 교육과 홍보 등을 권장하고, 관련 포스터 및 리플 렛을 개발 및 배포하고 있다 $[16,17]$. 그러나 교육 · 홍보의
대상인 직장인들이 인식하는 급식소의 나트륨 저감 관련 운 영현황을 파악한 자료는 거의 없는 것으로 나타났다. 나트륨 저감화를 위한 교육 · 홍보를 위한 교육매체 개발을 다양하 게 하고, 급식소의 자발적 저감화 유도를 위한 다양한 노력 을 하고 있으나, 관련 교육 · 홍보를 한 번도 경험하지 못했 다고 응답한 고객이 $69.7 \%$ 에 달했다. 아직까지 많은 급식소 에서 나트륨 저감화에 관심을 가지지 않고 있으며, 나트륨 저 감화에 참여하고 있더라도 직장인들은 교육 · 홍보에 대한 인식이 낮은 것으로 파악되었다. 영양교사를 대상으로 한 Lee [6]의 연구에서는 나트륨 저감화 교육을 받은 영양사는 $64.5 \%$ 였고, 교육을 받은 조사대상자들은 대부분 긍정적인 것 (약간 그렇다 $70.6 \%$, 매우 그렇다 $16.9 \%$ )으로 조사되었 다. 제공받은 나트륨 저감화 관련 교육 콘텐츠의 경우는 연 령별 인식 차이가 있는 것으로 나타났는데 $(P<0.01), 20$ 대는 '나트륨 저감을 위한 조리법'을 가장 많이 인식하고 있 었고, 30 대 이상에서는 '나트륨과 질병 및 혈압과의 관계'에 대해서 인식하는 응답자가 더 많은 것으로 조사되었다.

고객의 나트륨 저감화 급식에 대한 필요성 인식조사에서 는 나트륨 섭취를 줄이기 위해 양념 및 소스류를 따로 제공 할 필요가 있다’가 3.88점 (5점 만점)으로 가장 높은 점수를 보였다. 산업체 급식소 이용 고객들을 대상으로 한 Yoon \& Kang [27]의 연구에서는 고객들의 나트륨 섭취를 줄이기 위 한 노력으로 '짜게 느껴지는 음식을 덜 먹는다(3.40점)', '국 과 반찬의 양을 적게 담는다(3.22점)', '국물보다 건더기 위 주로 먹는다(3.19점)', '양념을 따로 덜어서 적게 먹는다 (3.18점)' 순으로 나타났다. ‘저나트륨 식단을 제공할 필요 가 있다,는 3.87점을 보였고 연령에 따른 차이는 나타나지 않았다. 영양사를 대상으로 한 Shin[30]의 연구에서는 나트 륨 저감화 중요성에 대한 인식조사에서 4.30점 (5점 만점) 을 보였고, 연령이 낮고 근무 경력이 짧을수록 나트륨에 대 한 중요도를 낮게 인식하는 것으로 나타났다. 영양교사를 대 
상으로 한 Lee[6]의 연구에서는 식단 작성시 영양소의 중 요도를 조사한 결과, 나트륨은 3.20점을 보여 조사 대상 영 양소에서는 가장 낮은 점수를 보였고, 급식 시 나트륨 저감 화의 중요도는 매우 높게 인식하는 편이었다 (중요하다 $55.6 \%$, 매우 중요하다 40.5\%). Matte [31]의 연구에서는 8 12주 동안 나트륨 제한식을 한 사람들에게 저염 식품의 맛에 대한 선호도가 증가하여 장기적이고 지속적으로 나트륨을 줄인 식 단을 제공하는 것이 바람직하다고 하였다.

나트륨 급식소 운영 필요성 인식조사에서 '나트륨 섭취를 줄이기 위해 ‘국 없는 날’을 시행할 필요가 있다' 항목은 3.14 점을 보여 가장 낮은 점수를 보였다. '나트륨 섭취를 줄이기 위해서 급식소는 김치보다는 생채소를 더 많이 제공해야 한 다'에 대해서는 3.36점을 보였으며 연령에 따른 차이는 없 었다. 국민건강영양조사 자료 분석으로 조사한 Song 등 [32] 과 Yon 등 [33]의 연구에서 김치는 나트륨 주요 급원 음식 군 1순위로 조사되었고, $\mathrm{Yu}$ 등 [34]은 저염 김치를 도입한 다면 나트륨 총 섭취량 감소에 영향이 미칠 수 있다고 하였 다. 중학교 점심급식의 소금함량 분석을 한 Park \& Lee [17] 의 연구결과, 일품밥 · 면류 $(1.96 \mathrm{~g})>$ 찌개류 $(1.38 \mathrm{~g})>$ 찜류 $(1.13 \mathrm{~g})>$ 탕류 · 국류 $(1.05 \mathrm{~g})>$ 김치류 $(0.88 \mathrm{~g})$ 순으로 소금함량이 높게 나타났다. 남성 성인을 대상으로 한 $\mathrm{Heo}$ 등 [35] 과 주부와 직장인을 대상으로 한 Ahn[36]의 연구에서는 영양교육 후에도 김치관련 식행동이 개선되지 않 았다고 하였다. Son 등 [37]은 대체염 사용과 저염 김치 개 발이 필요하고 김치의 섭취를 줄이기 위한 다양한 교육 · 홍 보가 필요하다고 하였다. 본 연구에서는 '건강을 위해 급식 은 심심하게 조리해야 할 필요가 있다'에 3.71점을 보였으 며 50대 (3.98점)가 유의적으로 필요성을 높게 인식하고 있 었다 $(P<0.01)$. 주부를 대상으로 한 Baek 등 [26]의 연구 에서는 '평상시 식생활에서 소금을 적게 먹는 것이 필요하다 고 생각한다, 문항에서 $89.1 \%$ 응답자가 필요한 것으로 생 각하고 있었고, '식당 또는 급식에서 싱겁게 조리된 음식을 제공 시 선택하겠다'는 대상자가 $77.8 \%$ 로 저염식의 필요성 을 느끼고 있었다.

'급식소는 나트륨 섭취를 줄이기 위한 전반적인 식생활 실 천방법에 대한 교육 및 홍보 자료를 제공할 필요가 있다'의 항목에서는 3.71점을 보였다. Shin 등 [38]은 나트륨 저감 화 영양교육을 통한 나트륨 섭취를 의식적으로 줄이는 것이 필요하다고 하였다. 다양한 연구에서 급식의 나트륨 저감화 를 위해서는 저염 급식 제공과 함께 나트륨 저감화 교육을 통 해 나트륨의 건강 위해성 및 심각성을 알리는 것이 중요하다 고 하였다 [38, 39]. 주부를 대상으로 한 질적 연구 [36]에 서 저염식을 제공하기 어려운 주된 이유는 가족들의 음식 맛
에 대한 불평인 것으로 조사되었다. 급식을 제공받는 고객들 의 불평이 있는 경우 저염식단을 제공하기 어려우므로 교육 과 홍보를 통해 고객들에게 저나트륨 급식 운영의 중요성을 알리면서 저나트륨 식단을 단계적으로 제공하는 것이 중요 하다고 사료된다.

산업체 급식 피급식자들을 대상으로 한 Yoon \& Kang [27]의 연구에서는 저나트륨 식단이 건강에 이로운지에 대 한 인식에서는 평균 3.77점 (5점 만점)을 보였고, '그렇다' '매우 그렇다라는 응답이 $65.6 \%$ 로 높았으며, ‘보통이다'는 $30.4 \%$ 로 조사되었다 [27]. 또한 저나트륨 식단에 대해서는 '영양적이다'라는 인식은 3.12점으로 가장 높았고, 다음은 '위생적이다(3.02점)', '신선하다(3.00점)' 순으로 나타났 다. 본 연구에서는 '저나트륨 식단이 건강에 도움이 된다고 생각한다’가 4.13점을 보였고, ‘저나트륨 식단은 영양적으 로 우수하다'는 3.61점을 보여 Yoon \& Kang [27]의 응답 자보다 대체적으로 저나트륨 식단에 대해 더 높은 인식을 보 였다. ‘급식의 저나트륨 식단은 나의 식생활 개선에 중요한 역할을 한다'는 3.79점으로 조사되었고 50대에서 가장 높 은 인식을 보여 연령에 따른 차이가 있는 것으로 나타났다 ( $P<0.05)$. Chung [39]의 연구에서는 연령에 따른 나트륨 에 대한 인식에 차이가 없는 것으로 나타나 본 연구와 차이 가 있었다. 본 연구에서는 '급식의 저나트륨 식단은 새로운 레시피가 개발된 것으로 생각한다’의 항목에 대해서는 3.52 점을 보였다. 영양교사를 대상으로 한 Lee[6]의 연구에서 는 나트륨 저감화 메뉴개발의 중요도에 대한 인식은 '약간 중 요하다'가 $52.9 \%$, '매우 중요하다'가 $42.7 \%$ 로 매우 높은 편으로 조사되었다. 대구지역 영양교사들의 나트륨 저감화 인식도에서는 ‘중요하다' $88.9 \%$, ‘메뉴개발이 필요하다’가 $87.1 \%$ 로 조사되었다[30].

고객들의 '건강관심도'는 '나트륨 저감 급식 운영 필요성 인식 ( $\beta=0.284, P<0.001)$ '과 '나트륨 저감 급식 운영 필 요성 인식 $(\beta=0.381, P<0.001)$ '에 정 $(+)$ 의 영향을 미 치는 것으로 조사 되었다. 본 연구 대상인 직장인들의 저나 트륨 식단에 대한 인식을 향상시키기 위해서는 대상의 특성 을 고려한 교육 컨텐츠 개발과 실천방법 등을 구체적으로 제 시할 필요가 있다. 대상별, 지역별로 체험형 프로그램을 실 시하고 대국민 인식 개선 목적의 TV, 라디오, 신문 등의 대 중매체 공익 광고를 통해 나트륨 줄이기의 필요성 및 실천방 법을 홍보할 필요가 있다 [16]. 주부, 학부모, 직장인을 대상 으로 한 Ahn 등 [24]의 연구에서 직장인 집단은 다른 집단 보다 나트륨 섭취 줄이기 실천에 대한 인식 및 자아효능감이 낮은 것으로 나타났고, 개별적 문항에서도 '반찬은 간이 맞 아야 한다고 생각한다'의 문항을 제외한 모든 문항에서 점수 
가 낮은 것으로 나타났다. 또한 직장인들은 나트륨 줄이기 영 양교육 프로그램을 실시한 후에도 ‘저나트륨식을 실천하면 나의 건강이 개선될 것이다'와 '가공식품과 인스턴트식품보 다는 신선식품을 구매하겠다'에 대해 자아효능감의 점수가 상승하지 않았는데 [24], 이는 근본적인 인식 전환이 필요함 을 시사하는 것으로 판단된다. 직장인의 연령대, 관심 사항, 시간적 제한, 바븐 근무 스케줄, 급식 이용 횟수 등의 특성을 고려한 교육 · 홍보 매체를 이용하여 현실적으로 직장인들이 실천 가능한 나트륨 섭취 줄이기 방법 등을 제시하고, 단계 적으로 나트륨 저감 급식을 제공하여 인식의 전환이 가능하 도록 해야 한다.

\section{요약 및 결론}

본 연구는 서울지역 산업체 급식소 이용 고객 340명을 대 상으로 건강관심도, 나트륨 저감 급식 운영 필요성, 저나트 륨 식단 인식을 조사하여 연령별로 비교하고, 고객의 건강관 심도가 나트륨 저감 급식 운영 필요성 인식과 저나트륨 식단 인식에 미치는 영향을 분석하였다. 응답자는 20대, 30대, 40 대, 50 대가 각각 $25 \%$ 로 구성되어 있고, 사무실 근무자가 $77.1 \%$, 점심 급식의 주당 이용횟수가 5회인 응답자가 $42.1 \%$ 였다. 이용 급식소는 $50.9 \%$ 가 염도를 게시하지 않았고 저나 트륨 식단을 전혀 제공하지 않는 급식소가 $51.8 \%$ 였으며, 제 공 식단의 간이 ‘보통이다’라고 응답한 고객이 $67.4 \%$ 로 가 장 많았다. 고객의 건강관심도에서는 '나는 건강에 관심이 많 다(3.56점)'가 가장 높은 점수를 보였고, 다음으로는 '나는 정기적으로 건강검진을 받고 있다'가 3.54점으로 조사되었 으며 20대의 점수가 3.00점을 보여 다른 연령대보다 점수 가 유의적으로 낮은 것으로 조사되었다 $(P<0.001)$. 나트 륨 저감 급식 필요성 인식에서는 '나트륨 섭취를 줄이기 위 해 양념 및 소스류를 따로 제공할 필요가 있다'가 3.88점으 로 가장 높은 점수를 보였다. '나트륨 섭취를 줄이기 위해 '국 없는 날'을 시행할 필요가 있다'가 3.14점으로 가장 낮 은 점수를 보였으며 30대의 점수가 2.80점으로 가장 낮은 점수를 보여 연령대별 인식 차이가 있는 것으로 조사되었다 $(P<0.01)$. 저나트륨 식단에 대한 인식은 ‘급식의 저나트 륨 식단은 건강에 도움이 된다'가 4.13점으로 가장 높은 점 수를 보였고, 다음으로는 '급식의 저나트륨 식단은 나의 식 생활 개선에 중요한 역할을 한다'가 3.79점을 보였으며, 50 대에서 4.00점의 가장 높은 점수를 보여 다른 연령대보다 유 의적으로 높은 인식을 나타냈다 $(P<0.05)$. '건강관심도'가 '나트륨 저감 급식 운영 필요성 인식 $(P<0.001)$ '과 ‘저나 트륨 식단 인식 $(P<0.001)$ '에 정 $(+)$ 의 영향을 미치는 것
으로 조사 되었다. 산업체 급식소가 저나트륨 식사를 제공하 기 위해서는 고객들의 참여가 반드시 동반되어야 하므로 고 객의 나트륨 저감 관련 인식 개선을 위한 교육 및 홍보 캠페 인을 실시하여 고객 참여를 확대하는 것이 필요하다. 연령별 로 표준화된 영양교육 프로그램을 개발 · 보급하여야 영양교 육의 효율성과 효과성이 향상되므로 [40] 직장인 특성 및 연 령별 특성을 분석하여 교육자료를 개발할 필요가 있다. 직장 인들의 관심과 흥미를 유발할 수 있고, 바븐 직장인들의 특 성을 고려한 대중매체를 통한 공익 광고, 대중교통 모니터 및 생활밀착형 실천 정보, 페이스북과 $\mathrm{SNS}$ 를 통한 정보 제공 등 [16]으로 고객의 건강관심과 나트륨 저감 관련 인식을 증 가시킬 수 있다. 효과적인 산업체 급식의 나트륨 저감화를 위 해서는 직장인 대상 건강정보 제공 및 나트륨 저감화 실천 교 육을 통해 인식을 향상 시키고, 동시에 급식소에서 저나트륨 식단을 단계적으로 제공해야 한다. 또한 연구에 근거한 산업 체 나트륨 저감화 급식소 운영 가이드 및 교육 · 홍보 자료를 개발하여 제공해야 한다. 본 연구는 서울 일부 지역의 산업 체 급식소를 이용하고 있는 고객들을 대상으로 급식소의 나 트륨 저감화 운영실태와 필요성을 파악한 제한점을 가지고 있어, 연구결과를 모든 산업체 급식소 고객의 인식으로 일반 화하기에는 어려운 점이 있다. 그러나 이러한 연구결과는 산 업체 급식소의 운영실태와 고객들의 인식을 파악하기 위한 구체적인 근거로 활용되어 산업체 급식의 나트륨 저감화 운 영관리와 고객들의 인식을 개선하는 데 기여 할 수 있을 것 으로 사료된다.

\section{감사의 글}

This research was supported by the Daejeon University Research Grants (2019).

\section{ORCID}

Na Yoing Yi: https://orcid.org/0000-0002-1500-0199

\section{References}

1. Intersalt Cooperative Research Group. Intersalt: an international study of electrolyte excretion and blood pressure. Results for 24 hour urinary sodium and potassium excretion. BMJ 1988; 297 (6644): 319-328.

2. Elliott P, Stamler J, Nichols R, Dyer AR, Stamler R, Kesteloot H et al. Intersalt revisited: further analyses of 24 hour sodium excretion and blood pressure within and across populations. BMJ 1996; 312(7041): 1249-1253. 
3. Sacks FM, Svetkey LP, Vollmer WM, Appel LJ, Bray GA, Harsha D et al. Effects on blood pressure of reduced dietary sodium and the Dietary Approaches to Stop Hypertension (DASH) diet. N Engl J Med 2001; 344(1): 3-10.

4. He FJ, MacGregor GA. Effect of modest salt reduction on blood pressure: a meta-analysis of randomized trials. Implications for public health. J Hum Hypertens 2002; 16(11): 761-770.

5. Ministry of Health and Welfare, Korea Centers for Disease Control and Prevention. Korea Health Statistics 2017: Korea National Health and Nutrition Examination Survey (KNHANES VII-2). Cheongju: Korea Centers for Disease Control and Prevention; 2018.

6. Lee CH, Kim DI, Hong JL, Koh EU, Kang BW, Kim JW. Costbenefit analysis of sodium intake reduction policy in Korea. Korean J Community Nutr 2012; 17(3): 341-352.

7. The Korean Nutrition Society. Dietary reference intakes for Koreans 2015. Seoul: The Korean Nutrition Society; 2015. p. 645.

8. World Health Organization. Salt reduction [internet]. 2016 [cited 2019 Jan 12]. Available from: https:/www.who.int/news-room/ fact-sheets/detail/salt-reduction.

9. He FJ, Jenner KH, Macgregor GA. WASH-world action on salt and health. Kidney Int 2010; 78(8): 745-753.

10. Federal Food Safety and Veterinary Office $(\mathrm{CH})$. Salt strategy for 2013-2016: paper on a strategy for reducing salt consumption. Bern: Federal Food Safety and Veterinary Office; 2013.

11. Seoul Metropolitan Government, Division of Food Safety (KR). Comprehensive plan of reducing sodium intake in Seoul 2020. Seoul: Seoul Metropolitan Government; 2013.

12. Henney JE, Taylor CL, Boon CS. Strategies to reduce sodium intake in the United States. Washington, D.C.: National Academies Press; 2010. p.153-154.

13. Yun SM. Analysis trend for new sodium reduction strategy in U.S.A. Health Welf Policy Forum 2014; 209: 106-114.

14. Ministry of Health and Welfare (KR). The 3rd health plan 2020 (2011-2015). Seoul: Ministry of Health and Welfare; 2011.

15. Lim AH, Hwang JY, Kim KR. Evaluation of the sodium intake reduction plan for a local government and evidence-based reestablishment of objectives: Case of the Seoul Metropolitan Government. J Nutr Health 2017; 50(6): 664-678.

16. Jung JE. Policy trends of sodium reduction. Food Sci and Ind 2016; 49(2): 2-7.

17. Park SY, Lee KA. Study on the salt and sodium content of middle school lunch meals in Gyeonsangbuk-do area: Focus on application of 'SamSam Foodservice. J Korean Soc Food Sci Nutr 2016; 45(5): 757-764.

18. Lee DH, Kim SY, Bae IO, Lee HG. Dietary behaviors related to sodium intake of the middle school students in Seoul. J Korean Living Sci Res 2010; 30(2): 16-22.

19. Shim E, Yang YJ, Yang YK. Relationship between thresholds and self-assessed preference for saltiness and sodium intake in young women. J Nutr Health 2016; 49(2): 88-98.

20. Rho JO, Kim HA. A study on the knowledge, dietary behavior related to sodium, attitudes towards a low-salt diet of adults in the Jeonbuk area. Korean J Hum Ecol 2013; 22(4): 693-705.

21. Jang JY, Kim MJ, Han JS. A study on food frequency, dietary habits and nutrition knowledge of the elderly who intake high sodium. J Korean Soc Food Sci Nutr 2009; 38(10): 1362-1372.

22. Moon HO, Rho JO. Correlation analysis of sodium-related knowledge, dietary behavior, attitudes towards a low-salt diet and meal attitude guidance for elementary school teachers in Jeonbuk area. J Nutr Health 2017; 50(2): 180-191.

23. Lee JH. Awareness and practice of sodium reduction by elementary, middle and high school dietitians in Gyeonggi area. J East Asian Soc Dietary Life 2012; 22(6): 734-743.

24. Ahn SH, Kwon JS, Kim KM, Yoon JS, Kim HK. Evaluation of consumer nutrition education program to reduce sodium intake based on social cognitive theory. Korean J Community Nutr 2015; 20(6): 433-466.

25. Ahn Y, Kim KW, Kim KM, Pyun JW, Yeo IH, Nam KS. Nutrition knowledge, eating attitudes, nutrition behavior, selfefficacy of childcare center foodservice employees by stages of behavioral change in reducing sodium intake. J Nutr Health 2015; 48(5): 429-440.

26. Baek JY, Yi HY, Hwang JY, Kim KR. Effects of nutrition education program based on social cognitive theory for low sodium consumption among housewives living in certain regions of Seoul. J Korean Soc Food Sci Nutr 2017; 46(10): 1243-1252.

27. Yoon SJ, Kang KO. Status of recognition, effort, and satisfaction of customers on low-sodium diet in industry foodservice. J East Asian Soc Diet Life 2017; 27(2): 168-175.

28. Kim SH, Jeong YJ. Domestic and international trends in sodium reduction and practice. Food Sci and Ind 2016; 49(2): 25-33.

29. Lee KS. Use of salimeters and sodium reduction education in school foodservice in the Gyeonggi area. J Korean Diet Assoc 2013; 19(2): 173-181.

30. Shin JH. Perception of dietitians for reduced sodium intake in food service and development of sodium-restricted recipes [master's thesis]. Catholic University of Daegu; 2010.

31. Mattes RD. The taste for salt in humans. Am J Clin Nutr 1997; 65(S2): 692S-697S.

32. Song DY, Park JE, Shim JE, Lee JE. Trends in the major dish groups and food groups contributing to sodium intake in the Korea national health and nutrition examination survey 19982010. Korean J Nutr 2013; 46(1): 72-85.

33. Yon M, Lee Y, Kim D, Lee J, Koh E, Nam E et al. Major sources of sodium intake of the Korean population at prepared dish level: based on the KNHANES 2008 \& 2009. Korean J Community Nutr 2011; 16(4): 473-487.

34. Yu KW, Hwang JH. Fermentative characteristics of low-sodium Kimchi prepared with salt replacement. Korean J Food Nutr 2011; 24(4): 753-760.

35. Heo YR, Oh HY, Ro HK. Study of the characteristics of dietary behavior and the effects of nutrition education for sodium reduction according to the stages of behavioral change in sodium reduction of male adult subjects in Gwangju Jeonnam regions. J Nutr Health 2017; 50(5): 472-482.

36. Ahn SH. Development and evaluation of nutrition education program to reduce sodium intake for consumers based on social cognitive theory and stage of behavior change model [dissertation]. Catholic University of Korea; 2013.

37. Son SM, Huh GY, Lee HS. Development and evaluation of 
validity of dish frequency questionnaire (DFQ) and short DFQ using Na index for estimation of habitual sodium intake. Korean J Community Nutr 2005; 10(5): 677-692.

38. Shin EK, Lee HJ, Jun SY, Jung YY, Park EJ, Ahn MY, Lee YK. Development and evaluation of nutrition education program for sodium reduction in foodservice operations. Korean J Community
Nutr 2008; 13(2): 216-227.

39. Chung YS. Salt intake and dietary factors associated with salt intake in Korea [master's thesis]. Catholic University; 2006.

40. Son SM, Lee KH, Kim KW, Lee YK. Practice of nutrition education and counselling: Focus on child and adolescent. Seoul: Life Science; 2007.p. 10-11. 